\title{
Dialogando com os indígenas sobre a lacuna da fala indígena nos livros didáticos
}

Dialoging with the Natives about the Indigenous Speech Gap in Textbooks

\author{
Danielle Krislaine Pereira* \\ Luis Henrique Mioto** \\ Marisa Noda ${ }^{* * *}, 1$
}

\section{RESUMO}

A Lei 11.645/2008, que inclui no currículo oficial da rede de ensino a obrigatoriedade da temática História e Cultura Afro-Brasileira e Indígena, induz a pressupor que ocorreram mudanças na abordagem que a temática indígena recebe nos livros didáticos. Porém, o fato é que ainda há muito a fazer para obter uma aprendizagem mais significativa sobre povos indígenas. Nessa perspectiva, a instituição escolar é considerada uma aliada essencial para combater ideias e atos preconceituosos, e o livro didático é um instrumento importante nesse processo. Como, então, avançar na direção de um ensino/aprendizagem mais significativo sobre as sociedades indígenas? Neste artigo analisamos alguns livros didáticos que abordam a temática indígena e, também, as falas dos habitantes de Terras Indígenas do Paraná e Santa Catarina que entrevistamos,

\section{Abstract}

The Law 11.645/2008, which includes in the official curriculum of the education system the mandatory theme of AfroBrazilian and Indigenous History and Culture, induces the assumption that there have been changes in the approach that the indigenous theme receives in textbooks. However, the fact is that there is still much to be done to achieve a more meaningful learning about indigenous peoples. From this perspective, the school institution is considered an essential ally to combat ideas and prejudices and the textbook is an important instrument in this process. How, then, to move towards a more meaningful teaching/learning about indigenous societies? In this article, we analyze some textbooks that address with indigenous theme and the speeches of the people from the Indigenous Lands of Paraná and Santa Catari-

\footnotetext{
* Mestre em Educação pela Universidade Estadual de Londrina (UEL), professora da Educação Básica, Santo Antônio da Platina, PR, Brasil. danikrislayne@hotmail.com

** Doutorando em Educação pelo Programa de Pós-Graduação em Educação, Universidade Estadual de Londrina (UEL), Londrina, PR, Brasil. luismioto@yahoo.com.br

*** Universidade Estadual do Norte do Paraná (UENP), Jacarezinho, PR, Brasil. mnoda@uenp. edu.br
} 
o que nos mostrou novos caminhos em prol de uma educação mais potente sobre a sociedade indígena.

Palavras-chave: livro didático; cultura e história indígena; identidade indígena. na that we interviewed, which showed us new ways towards a more potent education on the Indigenous society.

Keywords: textbook; indigenous culture and History; indigenous identity.

A diversidade cultural é tema indispensável em uma política educacional que proponha construir democracias multiétnicas e promover a paz e a coesão social mediante respeito e valorização da identidade. Assim, entendemos que os conteúdos referentes às diferentes etnias que formam as identidades brasileiras devem ser estudados desde os anos iniciais da Educação Básica. No Brasil, a existência da Lei 11.645/2008 leva a pressupor que tenham ocorrido mudanças no tratamento da temática indígena nos livros didáticos. Porém, uma vez que ainda há muito a fazer para alcançar uma aprendizagem mais significativa sobre esses povos, é necessária uma análise crítica sobre o modo como os manuais didáticos abordam a temática indígena. Como alerta Bittencourt (1998, p. 73), "é necessário enfatizar que o livro didático possui vários sujeitos em seu processo de elaboração...”. Nessa perspectiva, compreendemos que as narrativas históricas contidas nos livros didáticos são sempre decorrentes de escolhas políticas de seus produtores e das circunstâncias que influenciaram essa produção.

Segundo a avaliação realizada pelo Programa Nacional do Livro Didático (PNLD) de 2017, há lacunas importantes sobre a temática indígena nos livros didáticos atuais. Segundo consta no texto introdutório do Guia PNLD 2017 (Brasil, 2016), o tratamento da temática indígena ainda se coloca como o componente mais frágil no conjunto das obras didáticas aprovadas. A equipe que trabalhou na avaliação dos livros destacou essas fragilidades e a necessidade de ampliação e investimento em pesquisas relacionadas à temática indígena. Já no texto introdutório desse Guia indica-se que nas coleções aprovadas o tratamento das sociedades indígenas incorre nestas questões:

1) A diversidade de povos indígenas é contemplada de forma breve;

2) Temática indígena, quando evocada, mostra-se presente, muitas vezes, na abordagem da sociedade colonial brasileira; 
3) Há carência de orientações teórico-metodológicas para o professor quanto à abordagem da temática indígena;

4) Há problemas por apresentar dados genéricos sobre o passado, sem adentrar a especificidade de cada grupo;

5) Não se promove uma discussão mais efetiva da história e da luta dos povos indígenas na contemporaneidade;

6) Não se promove uma melhor representação da diversidade étnica da população brasileira.

Para o pesquisador José Ribamar Bessa Freire (2000) há cinco ideias equivocadas dos brasileiros sobre os povos indígenas:

1) Consideram o índio genérico, apresentando todas as etnias como iguais;

2) Consideram a cultura desses povos como atrasadas;

3) Consideram o congelamento de suas culturas, imaginando os índios nus ou de tangas, de arco e flecha, como descrito por Pero Vaz de Caminha;

4) Acreditam que os índios pertencem somente ao passado;

5) Os brasileiros não consideram a existência do índio na formação da sua identidade enquanto brasileiros.

Já as pesquisadoras Ernesta Zamboni e Maria Aparecida Bergamaschi constataram que ainda há na escola e no material didático que nela circula a predominância destas ideias:

a) índio genérico, em que a pluralidade das identidades étnicas fica completamente apagada; b) índio exótico, bárbaro, apresentado por diferenças em sinais diacríticos muito específicos e descontextualizados culturalmente; c) índio romântico, vinculado à ideia do bom selvagem, apresentado, sempre no passado, como uma figura ambígua, de herói e perdedor; d) índio fugaz, que anuncia um fim inexorável, seja pelo extermínio físico ou por processos de assimilação à sociedade nacional e, por fim, e) índio histórico, concepção mais recente que enfatiza a historicidade, a dinâmica cultural das sociedades indígenas. (Zamboni; Bergamaschi, 2009, p.10) 
Como, então, avançar na direção de um ensino/aprendizagem mais significativo sobre as sociedades indígenas? Neste artigo, primeiramente apresentamos as falas dos indígenas com os quais dialogamos sobre a temática, abrindo a reflexão sobre essas questões com a fala de vários indígenas que entrevistamos em Terras Indígenas do Paraná e de Santa Catarina. Em um segundo momento, analisamos criticamente a abordagem da temática indígena em duas coleções de livros didáticos.

\section{A CONTEMPORANEIDADE DOS POVOS INDÍGENAS}

O antropólogo Spensy Pimentel (2012, p. 11) afirma que os maiores obstáculos enfrentados pelos brasileiros para entender os indígenas não estão naquilo que eles não sabem, e sim naquilo que pensam saber sobre os indígenas.

Nos estados do Paraná e de Santa Catarina, onde se realizou nossa pesquisa, a ideia historicamente defasada de "vazio demográfico" - encontrada em alguns discursos oficiais, em painéis de museus históricos ou em livros didáticos - ficou marcada na historiografia tradicional, tornando-se comum encontrar a afirmação de que o atual território do Paraná só foi povoado entre o fim do século XIX e início do século XX, mediante a ação "civilizatória" promovida pelo governo da Província/Estado, sendo essas terras consideradas "devolutas, selvagens, desabitadas, [pois] estavam abandonadas, virgens, selváticas, sertão bravio, prontas para serem ocupadas e colonizadas" (Mota, 2008, p. 15). Porém, centenas de estudos comprovam a existência de populações antes da chegada dos colonizadores, e as evidências contrariam a ideia de um território desabitado. Segundo Mota (2008), as populações que aqui viveram, entre 12.000 e 3.000 anos antes do presente, são denominadas pela arqueologia como caçadores e coletores pré-históricos, e milenarmente as populações indígenas Kaingang, Xokleng, Guarani e Xetá ocupam a região.

Provavelmente, quando se pensa na história e cultura indígena, o que nos vem à memória são os conhecimentos adquiridos na infância, geralmente vinculados à comemoração do Dia do Índio, em 19 de abril. Em homenagem aos indígenas as crianças se fantasiam, colocam na cabeça um cocar - normalmente confeccionado com uma pena - e pintam o rosto. Em algumas escolas são comuns as apresentações por meio de música, dança, poema ou representações nas quais as crianças, com a mão na boca, fazem sons e gestos que remetem a 
uma ideia ritualística dos povos indígenas. Não se pode esquecer a imagem do índio a ser colorida pelos alunos, um índio seminu, com rosto e corpo pintado, usando arco e flecha e morando em uma oca. Essa imagem estereotipada e genérica ainda está presente em muitas salas de aula e faz parte do pensamento de muitos brasileiros.

Julio Cezar Melatti (1994) afirma que poucos conhecem a história dos indígenas brasileiros. O que a maioria da população brasileira sabe a respeito dos povos indígenas advém de conhecimentos socializados nos anos iniciais da escolarização. Diante disso, é nítido que a nossa sociedade ainda propaga um saber etnocêntrico, ocasionando a exclusão social de grupos étnicos. A partir desse entendimento torna-se relevante a abordagem sobre o livro didático no processo de ensino e aprendizagem. Esses livros tornam-se um recurso básico para o aluno e para o professor, sendo o principal, quando não o único recurso didático utilizado na sala de aula.

\section{A voz DOS INDÍGENAS SOBRE OS LIVROS DIDÁTICOS}

As entrevistas que realizamos durante o ano de 2017 com algumas lideranças indígenas de Terras Indígenas da região do norte do Paraná e de Santa Catarina permitem perceber a insatisfação dos indígenas ao verem suas histórias sendo silenciadas ou sem valorização adequada. Diante do exposto, cabe-nos relatar as valiosas opiniões dos protagonistas desta pesquisa, os representantes das etnias Kaingang, Guarani e Xetá: eles expõem suas angústias, sofrimentos e também as lutas por um ensino mais significativo sobre as sociedades indígenas.

Segundo o professor Jefferson Gabriel Domingues, Guarani da Terra Indígena Pinhalzinho (localizada no norte do Paraná), as informações errôneas que estão nos livros didáticos são propositais e têm o intuito de favorecer o conceito já ultrapassado de "aculturação", negando a existência dos indígenas atuais, simplesmente por não estarem com vestimentas e acessórios que usavam há mais de 500 anos:

quando se trabalha esse tipo, com materiais, com as publicações dos livros, das editoras, trabalhando o indígena como um índio de 1500, está uma intenção, é intencional. O objetivo deles é anular o conhecimento dos indígenas hoje, é dizer 
que se o índio não vive segundo aquele padrão que tá naquela época, o índio da visão de quem estuda é somente aquele índio de 1500. Então, quando ele vê o índio de hoje, ele não consegue, não consegue ver o índio como índio. Se ele não parece com o índio de 1500, então o que acontece? Nós vemos nisso um grande ataque. E isso é eu que estou dizendo, é proposital, porque o nosso povo continua a luta de 500 anos atrás, continua ainda. A luta é a mesma, a manutenção da língua, a restauração do território, a garantia da autonomia para viver com a sua filosofia de vida. Essa luta é a mesma. Só que as ferramentas para se lutar são outras, o modo para sobreviver hoje são outros [...] e nós entendemos que todo livro didático tem uma intencionalidade, parte de uma intencionalidade. [...] tem a editora, tem o Estado que busca a publicação, e atrás disso tem essa intencionalidade que quer o quê? Quer é apagar o índio, mostrar que como ele não se parece com aquele índio de 1500, então não dá muita visibilidade, então não aparece nem no livro didático nem na televisão, nem nos meios de comunicação. O movimento indígena causa o quê? Ele causa um pouco de medo na sociedade majoritária hoje, sendo que não deveria acontecer isso, porque a diversidade é importantíssima, porque a diversidade é muito rica, muitos dos desastres, muitos dos problemas, muitas das dificuldades que existem na sociedade, a nossa forma de ver, nossa forma diferente de ver poderia trazer soluções para muitos desafios dos problemas deles, mas eles têm um sistema único de viver, eles têm o sistema único de enxergar as coisas e eles acabam, eles têm medo de dar essa visibilidade, isso que nós entendemos. E a questão do livro didático não trazer como nós somos hoje é uma agressão, é intencional mesmo. (Domingues, 2017)

Nota-se, segundo Domingues, o indígena sendo apresentado somente na visão do passado, como ocorre na maioria dos livros didáticos, fato este que ajuda a favorecer uma ideia equivocada. A criança passa a acreditar que o indígena deixou de ser indígena, pois já não se parece com o índio de 1500, mas o processo histórico-social é muito mais complexo que essa visão simplificadora.

Sobre esse assunto, analisemos a fala de Cristiano Góje Jorge, Kaingang da Terra Indígena Apucaraninha (localizada no norte do Paraná) e que faz parte do grupo de canto e dança cultural "Nen Gá", comentando sobre as pinturas de sua cultura: 
Porque as nossas pinturas... nós fizemos essa aqui só pra apresentar. Agora, quando é pra tipo de luta, nós pintamos todo o corpo, assim, de preto assim, porque é tipo de confronto, nós estamos ali pra buscar o que é nosso, estamos brigando, então nos pintamos de preto assim, essas coisas. Geralmente muitos falam assim: "Os índios só se pintam quando estão precisando de alguma coisa". Mas é verdade isso aí. Igual vocês, né? Ontem vocês se apresentaram aqui, daí vocês usaram seus pertences ali, [...] nós também somos assim, quando por exemplo, estamos assim, nos pintamos porque estamos mostrando nosso trabalho pra vocês. Igual um advogado, se ele for defender algo, no júri, ele tem que ir de terno, ele não vai igual vocês, assim, normal. E daí muitos falam assim: "Os índios só se pintam pra se mostrar". Nós nos mostramos porque é nosso direito também, nossa cultura. (Jorge, 2017)

Cristiano tenta explicar para nós, não indígenas, o uso da pintura em sua comunidade. Explica que são julgados de forma preconceituosa por muitos não indígenas que os acusam de usarem a pintura "só quando querem alguma coisa". Afinal, a pintura dentro da comunidade Kaingang é ainda hoje muito utilizada para vários fins, em rituais e festas da comunidade, tem grande importância política e cosmogônica. Presenciamos vários desses usos em muitas ocasiões. Frisamos ainda que, obviamente, não compreendemos a totalidade da importância das pinturas para essas comunidades, temos de ter a humildade de assumir nossa condição de outro, um outro que busca se aproximar de uma cultura que não é nossa e que projeta a construção de conceitos e exercícios de compreensão de uma comunidade absolutamente singular e única. A pintura é muita coisa e serve também como uma espécie de "uniforme" de luta e de reivindicação - como os advogados que vão às audiências em juízo, compara o Kaingang Cristiano... Compara para aproximar-nos de uma imagem conceitual, para que possamos compreender minimamente o que significa a pintura para eles.

Já o forte e impactante depoimento da professora Ana Paula Goj Téj Narciso, Kaingang da Terra Indígena Xapecó (em Santa Catarina), amplia-nos a concepção do uso dos elementos da cultura tradicional no cotidiano contemporâneo de uma Kaingang:

Nós indígenas, nós somos acostumadas a se enfeitar, nós usamos colar, nós usamos aqueles brincos. Hoje eu não uso muito, sabe por quê? Porque ele te 
caracteriza indígena, e não precisa ter aquilo para ser indígena. Se eu for em uma palestra, às vezes eu vou com um colar, mas a minha fala vai dizer quem que eu sou. Não precisa eu estar toda emperiquitada com cocar, pelada, pintada para dizer que eu sou Kaingang. Não. Eu posso usar os meus anéis, posso usar os meus brincos, eu posso arrumar minha sobrancelha do jeito que eu quiser, que vou sempre ser a Ana Paula Kaingang. Não vou deixar de ser Kaingang. E muitos, eles nos caracterizam por isso: se você está de brinco, se você está de cocar, se você está pintado, você é indígena. Não! A sociedade não indígena tem que saber que nós somos indígenas de roupa, nós somos indígenas de salto alto... Eles têm que nos reconhecer por causa disto: pela nossa fala, pela nossa luta, pela nossa língua, pelo jeito de nós vivermos, só isso. Porque nós não podemos negar! Eu não vou negar que eu gosto de usar um salto alto. Se vocês me verem de noite por aí, eu sempre vou estar de salto alto. [...] Tem palestras que eu vou, vou pintada, tem palestra que eu vou de cocar, vou de colar. Na minha casa, se você for lá tem uma parede que está cheia, eu tenho uns duzentos cocares, brincos e coisarada, tem tudo lá na minha parede! Mas quando eu acho necessário fazer isso, quando tem uma apresentação, alguma coisa, quando não tem... Se você vai me aceitar do jeito que eu sou, o problema vai ser teu se você vai aceitar, e o objetivo que eu tenho é mostrar que nós somos indígenas Kaingang e que nós temos o direito de andar onde nós quisermos e vestir e comer o que nós quisermos. Então o meu objetivo é esse, que não é porque eu sou Kaingang que eu sou inferior ao outro. Nós somos iguais, iguaizinhos, só a cultura que difere. (Narciso, 2017)

Sabe-se que atualmente nenhum não índio se veste como Pedro Álvares Cabral e nem por isso deixa de ser brasileiro. Aceita-se que todas as culturas sofrem transformações, no entanto, o discurso preconceituoso não aceita essas transformações quando se refere aos indígenas. Se o indígena usa relógio, celular, ou simplesmente veste uma roupa, acaba sendo definido como aculturado e como não índio. A calça jeans, por exemplo, não é uma invenção brasileira, tantos brasileiros a usam e não se tornam norte-americanos, ou ninguém se torna japonês ao gostar de comer sushi, mas quando um indígena compra uma moto ou usa um relógio o discurso julgador preconceituoso rapidamente já considera "aculturado" ou um "indígena” que "não é mais tão indígena”.

É importante ressaltar que todos os entrevistados compartilham da opinião de que o livro didático é um grande propagador desse conhecimento 
impreciso. O professor Pedro Pablo Velásquez - Guarani e professor da Universidade Estadual de Maringá (UEM), com mestrado em Letras pela Universidade Estadual do Oeste do Paraná (Unioeste) e graduação em Letras pela União Pan-Americana de Ensino - relata que:

O livro didático é um instrumento que pode ser um instrumento para levar uma pessoa a ter o conhecimento real, mas ele pode ser um instrumento nocivo para a sociedade. O livro didático é um guia do professor, e o professor sempre pensa que tem que seguir o livro didático. Se assim não for, não vale o ensino. Não é assim que funciona com os indígenas, [...] se lá na comunidade não indígena já não funciona esse livro didático, muito menos em uma sociedade que não tem nada a ver a não ser a língua, mesmo. Eles falam, eles são bilíngues e precisam falar português... (Velásquez, 2017)

O professor Claudinei Ribeiro Alves, Guarani Nhandewa da Terra Indígena Posto Velho, ao ser questionado como avalia a sua história e cultura no livro didático, discorre sobre os estereótipos contidos nos livros: “a carta de Pero Vaz de Caminha foi uma coisa que ele viu, e de lá para cá tanta coisa mudou, mas no livro parece que não mudou nada”. Velásquez (2017) também chama a atenção para essa questão:

Outra coisa é uma visão estereotipada, e esse é um grande pecado também. Eles acreditam em uma visão hegemônica, que creem que o indígena não pode ter celular, ele tem que morar no mato, tem que criar animais, tem que viver da caça. Essa é uma visão não indígena, que foi imposta pelo não indígena justamente para relegar a segundo plano. Além disso, é uma política nociva, é nocivo no letramento, é nocivo no conceito para os indígenas, é nocivo no conceito do que é uma sociedade. (Velásquez, 2017)

Para Claudinei Ribeiro Alves (2017) os indígenas são vistos de forma homogênea:

Sabe por que aconteceu essa ideologia que tem até hoje? Segundo eu fiz pesquisa em fontes verídicas, para os Terena, os Guarani, os Kaingang, os povos indígenas que ocupavam as terras no Brasil na época da colonização, eles fizeram uma aldeia muito grande e o que aconteceu eles misturaram Guarani, Terena... Por exemplo, lá para cima tinha Terena e eles queriam tomar posse, mas não tem 
como, então faz uma aldeia grande para todo mundo e coloca todo mundo lá [...], mas tinha bastantes etnias com línguas diferentes, e essa ideologia veio porque ninguém sabia diferenciar Terena, Kaingang, Pataxó e outras etnias. A história do Brasil fala que a maioria era Tupi, pode ver que a maioria das coisas nomeadas no Brasil é Tupi, mas isso não quer dizer que só tinha Tupi e que todos os índios são iguais. Somos iguais em uma parte. Somos todos ligados à natureza, se você mata uma árvore você vai matar você mesmo, quando você derruba uma árvore você está deixando de respirar um ar puro, isso é falado entre a gente, mas o livro generaliza tudo. (Alves, 2016)

Percebemos que os indígenas entrevistados demonstraram, no decorrer das entrevistas, muita insatisfação diante do que já viram e que infelizmente ainda continuam vendo nos livros didáticos. O professor Claudinei Alves cita o que mais o marcou negativamente em um livro didático:

Eu lembro que eu li no livro que o índio faz a dança da chuva, mas o que é a dança da chuva para os brancos? O que ele tem a falar sobre a dança da chuva? Será que existe mesmo a dança da chuva? Porque também pode ter a dança do fogo, tem a dança do milho, não tem só a dança da chuva, cada coisa tem um significado, mas daí você lê no livro didático que só tem a dança da chuva. Eles fumam o cachimbo da paz, outra coisa que já li... (Alves, 2016)

Em relação à "dança da chuva" e ao "cachimbo da paz", é perceptível a falta de informação sobre os indígenas, os quais são retratados na mídia em geral de maneira equivocada e homogênea, pois não há preocupação em obter informações verídicas, ocorre sempre uma generalização.

Na entrevista com Suely Silva e seu irmão Dival Silva, da etnia Xetá da Terra Indígena São Jerônimo, vê-se o quanto as informações incorretas podem prejudicar a identidade de um povo. Para eles, uma das etnias mais prejudicadas com essas informações errôneas são os Xetá, pois além das informações incorretas apresentadas nos livros didáticos, também há falta de conhecimento e informação sobre essa etnia - em muitos livros nega-se até sua existência. Segundo Suely Silva os livros didáticos apresentam poucas informações e, o que é pior, distorcidas. Seu irmão Dival da Silva, indignado com essa falta de informação sobre seu povo, desabafou: 
As coisas não é do jeito que é para ser. Porque a gente teve analisando uns livros aí e tem muita coisa errada, desrespeito do nosso povo, fala que só existe 6 [Xetás], tem lugar que fala que existe só 6 , tem lugar que fala que não existe mais nada. Eu acho que isso é um grande desrespeito com o povo da gente, então a gente procura ver como vai fazer, para ver se consegue mudar a situação desse quadro aí, porque a gente sabe que a gente existe, a gente sabe que a gente está por aí lutando pelas causas da gente, e ultimamente as pessoas que não conhece a pessoa, o pessoal da gente, fica aí escrevendo coisas que não quer dizer nada. Então, por esse motivo até, nós lançamos um livro, lançamos um livro para podermos divulgar para as pessoas verem que a gente existe, porque isso, livro nenhum está contando. Né? (Silva; Silva, 2017)

Suely e Dival contaram que uma professora não indígena da Escola Indígena São Jerônimo, ao distribuir os livros aos alunos, notou que em uma das páginas constava que os Xetá não existiam mais, e havia fotos da morte de alguns Xetá. Imediatamente essa professora procurou Suely, que se emocionou ao ver a foto do seu pai morto. Indignada, ela comenta:

A professora estava fazendo um trabalho, aquela professora lá, a Keli, daí ela achou no livro e trouxe para eu ver, falou: “Olha, Sueli, é assim mesmo?”. Daí eu peguei o livro e vi tudo errado. E outra coisa: nós não autorizamos postar a foto do pai, foto da morte dele, e não tinha autorização de nenhum de nós. Eu falei "Isso daqui já tá errado", porque na verdade, para postar uma foto, morto ainda, tem que ter autorização, não tem? Alguém tem que autorizar, mas não, puseram no livro e escreveu o oposto do que era, daí que eu cheguei e falei para ele, daí a menina que faz trabalho aqui com a gente, daí ela perguntou para nós: "Suely, você quer tirar esses livros?". Daí nós pedimos para ela ajudar a gente a tirar. (Silva; Silva, 2017)

Presenciamos muito o desrespeito e falta de cuidado com a imagem dos sujeitos indígenas, e essa é uma grande crítica dos povos indígenas em geral que presenciamos, muitos pesquisadores e fotógrafos profissionais ou amadores entram em comunidades de maneira indelicada e invasora, sem prévia autorização, e realizam registros e pesquisas sobre a comunidade sem sequer devolver a eles, adequadamente, o resultado da fotografia ou pesquisa. Nota-se, também, nesse caso, que a ideia de vazio demográfico volta a estar presente. 
Os Kaingang hoje ainda lutam para comprovar sua existência durante a colonização de Londrina e região, para conseguirem reaver suas terras ancestrais. Já os Xetá lutam para comprovar sua atual existência:

Por enquanto pedi para eles tirarem os livros, mas se eles não tirarem esses livros, teremos que tomar uma decisão mais severa. Como vai postando uma coisa sem autorização nossa? E escrevendo de qualquer maneira, isso daí é como eu falei e continuo falando, é um grande desrespeito com a gente, tá achando que a gente é o quê? Quer dizer que não somos nada, que não tem ninguém para responder por nós? Para mim tá errado, ou eles fazem o pedido ou vamos entrar na Justiça para ver como é que fica, mas por enquanto pedimos só para tirar, e se alguém quiser escrever alguma coisa que venha até nós. Esse livro mesmo, as histórias estão todas guardadas na minha memória, se for para eu contar para vocês a história do meu povo eu levo de 2 a 3 dias para contar todas as histórias, e isso tudo foi meu pai que passou para mim. (Silva; Silva, 2017)

O professor Velásquez, Guarani, comentando sobre a Lei 11.645/2008 que inclui no currículo oficial da rede de ensino a obrigatoriedade da temática "História e cultura afro-brasileira e indígena" - faz uma crítica em relação aos métodos de trabalho da presente lei: "o material deles já não traz o que trabalhar, coloca uma lei, mas não coloca o instrumento correto, que lei é essa? Cadê o instrumento para aplicar essa lei? E uma lei para não ser cumprida e aplicada é mesmo inútil, é inútil” (Velásquez, 2017).

Ao ser questionado sobre as principais medidas a serem tomadas para que essa lei saia do papel, o professor Guarani Nhandewa Claudinei Alves sugeriu:

Trabalhar em cima dela, para fazer acontecer. Os saberes indígenas na escola é uma coisa muito interessante, é voltado bem mais para o planejamento específico de aula, apoia aquelas aulas que antigamente não podia sair, aula de geografia indígena, só ficava ali, naquela sala quente, calor e as crianças só ficava lá nas carteiras, com os livros e caderno, sendo que não é nem da cultura indígena isso. As crianças indígenas aprendem brincando... nós temos uma forma diferente de ensinar. (Alves, 2016) 


\section{ANALISE DA TEMÁTICA INDÍGENA NOS LIVROS DIDÁTICOS}

Apresentaremos agora uma análise que realizamos a respeito da imagem dos indígenas construída nos livros didáticos dos anos iniciais do Ensino Fundamental. Para tanto, investigamos duas obras: a coleção Porta Aberta (de 2011 $)^{2}$ da Editora FTD, elaborada pela escritora Mirna Lima, e a coleção História: sociedade \& cidadania (de 2015), também da Editora FTD e elaborada por Alfredo Boulos Jr. ${ }^{3}$

\section{Vamos à primeira análise:}

Na coleção Porta Aberta, nos seus quatro volumes, a temática indígena está presente, ainda que com abordagens qualitativamente distintas. No livro do $2^{\circ}$ ano, ao versar de forma genérica sobre o conteúdo "A criança”, são abordadas estas questões: diferenças culturais, costumes, modos de vida e as possíveis semelhanças entre diferentes crianças. No entanto, há somente uma imagem de criança indígena, sem explicações detalhadas sobre ela. Ao relatar o modo de viver de diferentes famílias, a autora cita um texto de Eunice Dias de Paula, "O nosso jeito de ensinar é assim”, com o intuito de levar os alunos a analisarem e perceberem a importância dos anciões para a cultura indígena. Ainda no mesmo volume, ao abordar histórias de diferentes famílias, a autora recorre ao texto "Um indiozinho entre dois mundos", do autor José Santos, e cita alguns aspectos da família indígena, com o objetivo de oferecer ao aluno informações sobre diferentes formas de organização familiar. No entanto, essas diferenças não são trabalhadas profundamente para que o aluno possa compreendê-las de forma contextualizada. Esse capítulo apresenta ainda a trajetória de uma criança indígena Xerente que mora com seus pais na aldeia do Sono, retratando como é a vida na aldeia e fora dela, e o que faz cada membro de sua família.

No volume destinado ao $3^{\circ}$ ano os povos indígenas são abordados com maior frequência. Comenta-se que há diferenças entre as culturas indígenas, mas elas não são descritas. Discutem-se as diferenças e semelhanças no que se refere ao modo de ser e agir de meninos e meninas de diferentes povos, como os indígenas, portugueses e imigrantes, modos de vida e religiões de diferentes culturas. Os costumes religiosos dos povos indígenas são relatados num texto de Yaguarê Yamã, "O dia em que encontrei o meu espírito protetor”, no qual a divindade descrita pode ser comparada à figura de um padrinho, a fim de promover uma melhor compreensão dos alunos a respeito dessa crença. A arte 
indígena também é citada, destacando-se a pintura corporal desses povos quanto a seus objetivos e confecção. No entanto, mais uma vez, os indígenas foram representados como se todos os povos tivessem a mesma crença, fizessem a mesma pintura, agissem e pensassem da mesma forma, desconsiderando a identidade cultural de cada povo e as especificidades religiosas complexas de cada comunidade.

O livro do $4^{\circ}$ ano apresenta textos e imagens referentes aos povos indígenas. O texto "Os Povos Indígenas e os Portugueses: Primeiros Contatos" relata a chegada dos portugueses e seu primeiro contato com os povos indígenas. A autora cita na obra a carta de Pero Vaz de Caminha e, logo após, faz alguns questionamentos sobre pontos relevantes desse documento:

Você percebeu que, logo ao chegarem, os visitantes descobriram que a terra já tinha dono? Será que havia ouro na terra ou o morador estava querendo levar os objetos para usá-los como enfeite? Você percebeu que os costumes dos primeiros moradores do território ainda são praticados no Brasil? Caminha informou ao rei que os habitantes não plantavam, nem criavam animais e também não tinham nenhuma crença, mas isso não era verdade. Ele não conhecia os costumes do povo e fez um julgamento precipitado. Caminha aconselhou o rei a salvar o povo da terra. Está certo fazer esse julgamento sem conhecer direito o povo e seus costumes? (Lima, 2011, $4^{\circ}$ ano, p. 45-48)

No texto "Descobrimento ou Invasão: o que pensam hoje os grupos indígenas" a autora apresenta um documento com a opinião de alguns indígenas sobre o encontro de dois povos diferentes em 1500, proporcionando um confronto entre os pontos de vista dos dois grupos. Outro texto abordado é "A primeira invasão de nossa terra”, onde lideranças indígenas expõem suas opiniões sobre a chegada dos portugueses. A autora fez algumas indagações, com o intuito de os alunos analisarem criticamente como realmente aconteceu o "descobrimento" do Brasil:

O narrador não concorda com os novos nomes que os portugueses deram aos lugares. Por quê? Essa atitude demonstra que eles já estavam ocupando a terra para serem donos dela? O narrador acredita que os indígenas sofrem hoje pelas terras que lhes foram retiradas. Ele tem razão em pensar assim? (Lima, 2011, $4^{\circ}$ ano, p. 51-52) 
Nesse livro a autora mostra a intenção de proporcionar uma reflexão sobre a vida atual dos indígenas e sobre a maneira como a invasão dos portugueses proporcionou danos a essa sociedade. No entanto, ela não apresenta, em nosso entendimento, ao leitor nenhum exemplo satisfatório de diferença entre os indígenas do passado e do presente. Prevalece um indígena estereotipado e pertencente apenas ao passado.

No livro do $5^{\circ}$ ano, a segunda unidade utiliza o título "Indígenas e Portugueses: Os Donos da Terra e os Conquistadores” para propor o estudo das relações estabelecidas entre os grupos indígenas brasileiros e os colonizadores portugueses. O livro revela reconhecimento de mudanças e permanências no modo de vida das populações indígenas em comparação a outras épocas - apesar de apresentar dados demográficos defasados sobre a população indígena:

Em 1500, os donos da Terra eram 4 milhões de pessoas, que faziam parte de 1.400 povos, distribuídos em todo o território que hoje forma o Brasil. Hoje são aproximadamente 600 mil pessoas, que fazem parte de 227 povos, que falam mais de 180 línguas e dialetos diferentes. Não são mais donos das terras, apenas têm o direito de viver nelas. ${ }^{4}$ (Lima, 2011, $5^{\circ}$ ano, p. 40-41)

Sob o título "Os Povos Indígenas: A vida nas Aldeias", o livro relata a história das Terras Indígenas Canela, Yawalapiti, Waiãpi e Kalapalo, mostrando os costumes e tradições dessas diferentes etnias:

Os Canelas, que fazem parte do povo Timbira, constroem aldeias circulares. O círculo é formado de maneira que todas as casas tenham a mesma distância do pátio e caminhos iguais que conduzem a ele, chamados caminhos radicais. No pátio, $o$ centro da aldeia, são tomadas todas as decisões políticas. Na frente das casas passa um caminho circular, chamado periferia, onde são realizadas as atividades domésticas. Os Yawalapiti que fazem parte do povo Aruaque também constroem suas aldeias em forma de círculo, com as casas dispostas na periferia e um espaço central formando um grande pátio. No meio do pátio fica a sepultura, onde são enterrados os capitães, isto é, os homens de maior prestígio, geralmente líderes dos grupos domésticos. Próximo à sepultura, mais afastada do centro, fica a casa dos homens ou casa das flautas, local de reunião que não é frequentado por mulheres. Os Waiápi, povo Tupi, constroem aldeias temporárias e aldeias definitivas. As 
aldeias temporárias seguem as roças e acompanham o ciclo agrícola, isto é, mudam, em média, a cada 5 ou 6 anos, quando ocorre o esgotamento do solo. As casas não são necessariamente reunidas em uma área central. Existem algumas habitações espalhadas, outras próximas às roças, e há também habitações reunidas junto a um centro de atração. (Lima, 2011, $5^{\circ}$ ano, p. 50)

Percebe-se que a autora expõe as diferenças relacionadas às Terras Indígenas, no entanto, o que predomina novamente é a análise da cultura tradicional dos indígenas.

Com o título "Você reconhece a importância do povo indígena?", a autora entra na discussão das diferenças entre os povos indígenas que viveram em nosso país no passado e os povos indígenas atuais, refletindo sobre as suas contribuições:

No passado, antes do ano de 1500, os grupos indígenas eram os únicos donos da terra. Hoje, os grupos indígenas lutam para ter direito de viver na terra onde o seu povo vive e conserva seus costumes e tradições. No passado, os grupos indígenas foram forçados a abandonar seus costumes, a aprender a falar uma nova língua e a praticar uma religião diferente da sua. Hoje, os professores das escolas das aldeias dão aulas na língua portuguesa e na língua falada pelo povo do lugar. No passado, os indígenas eram considerados, pela Constituição, como impossibilitados de se defender e por isso foram tutelados. Hoje, as lideranças indígenas falam em nome do seu povo e defendem seus interesses junto aos governantes. No passado, os indígenas praticavam seus costumes nas aldeias. Hoje, eles ainda fazem isso, isto é, conseguiram conservar seus costumes e tradições. Os alimentos, como a mandioca, o milho, o inhame e o guaraná, as festas, os banhos diários, as redes, as canoas, as jangadas, os cestos de palha e de cerâmica são hoje utilizados por todos os brasileiros. (Lima, 2011, $5^{\circ}$ ano, p. 58)

O conceito de "indígena" aqui é apresentado de forma genérica, homogeneizante da multiplicidade das etnias existentes. Há um limite problemático no pouco aprofundamento das características das multiplicidades e diferenças, e pouca presença da fala dos próprios indígenas sobre si mesmos.

Percebe-se então que a coleção Porta Aberta, publicada em 2011, apresenta em relação ao livro de Estudos Sociais, publicado em 1970, grande avanço ao contemplar e respeitar algumas das lutas dos indígenas, embora 
apresente pouco avanço em relação à imagem dos povos indígenas como sociedade contemporânea. Em grande parte mantém a imagem do indígena homogêneo e genérico, narrado quase que exclusivamente no período colonial, revelando que alguns velhos conceitos ainda permanecem inalterados.

\section{ANÁlise do LIVRo DidÁTICO EM UMA EsCOLA INDÍGENA}

Todas as Terras Indígenas visitadas têm escolas formais, com Ensino Fundamental e Médio, mais que a metade já constituída com professores, pedagogos e diretores indígenas. A base das ações educativas nas aulas formais ocorre com os alunos sentados nas carteiras das salas de aula, mediados pelo livro didático que chega até essas Escolas. Conversando com os professores, percebemos as lacunas problemáticas nesses livros didáticos que são trabalhados dentro das comunidades indígenas: os educandos e professores indígenas pouco se reconhecem no discurso presente nesses livros. Se até agora falávamos da problemática trazida por essas lacunas no ensino das Escolas não indígenas sobre a comunidade indígena, imaginemos a dimensão que isso toma se analisamos as lacunas nos livros didáticos que são trabalhados nas próprias Escolas indígenas.

Aqui, então, apresentamos nossa segunda análise:

$\mathrm{Na}$ Escola Indígena Benedito Rokág, da Terra Indígena Apucaraninha (localizada no norte do Paraná, perto dos municípios de Tamarana e Londrina), conversamos com a professora de História, que é não indígena, e solicitamos para análise os livros utilizados. Trata-se da coleção História: sociedade \& cidadania (Boulos Jr., 2015), que traz livros voltados para o Ensino Fundamental (a partir do $6^{\circ}$ ano) e todo o Ensino Médio.

A opinião crítica da professora a respeito da qualidade da temática indígena nos livros didáticos dessa coleção que trabalham por lá se parece muito com a crítica que realizamos da obra Porta Aberta: os indígenas são citados em diversos momentos ao longo dos volumes, porém quase sempre de forma genérica ou se referindo a sua cultura tradicional ou antepassada, pouco se aprofundando sobre as diferenças e singularidades das centenas de povos indígenas, sem quase nenhuma presença da fala do próprio indígena sobre as temáticas 
abordadas. A professora, no entanto, reconhece alguns trechos respeitosos presentes na coleção História: sociedade \& cidadania e a importância, mesmo que em poucos momentos, de a história e a cultura indígenas estarem ali representadas. Analisamos a obra, e as críticas da professora nos pareceram corretas.

Por toda a coleção analisada, a História parece se dar sem presença indígena. A sensação que nos passa como leitores é de que a História, tendo como protagonista a sociedade ocidental, está acontecendo quando, repentinamente, em poucos momentos muito específicos da narrativa, a figura do indígena emerge, como se tivesse estado à parte dos rumos da História. E aparece velozmente, descontextualizado, como se não fosse influenciado ou influenciasse todas as situações históricas narradas até então. Quando mostrados em épocas atuais, os indígenas são sempre apresentados pelo viés da sua cultura tradicional, com poucas discussões sobre a sua situação contemporânea. São, quase sempre, representados de forma genérica, sem sua fala própria. Localizamos apenas uma fala de indígena na coleção inteira. ${ }^{5}$

Especificamente, consideramos interessante uma página, a de número 222 do volume do $7^{\circ}$ ano. Ali apresentam-se imagens de três indígenas da América na discussão sobre o período colonial do século XVI, mas são três fotos tiradas nos anos 2000 - um Navajo (nos Estados Unidos), um Murato (na Bolívia) e uma Kalapalo (no Xingu, Mato Grosso) - com vestimentas tradicionais. Sob as fotos, esta pergunta: "O que é certo dizer: povo indígena da América ou povos indígenas da América?”. Achamos interessante a provocação à noção de multiplicidade dos povos indígenas, apesar de ser uma das poucas falas nesse sentido, pois a maioria dos textos contidos na coleção analisada aglutina a multiplicidade indígena numa imagem genérica.

No capítulo 5 do livro do $6^{\circ}$ ano há uma discussão importante sob o título "Os indígenas: diferenças e semelhanças". O autor anuncia que "cada povo possui a sua cultura própria” (p. 36) e que os indígenas falam línguas diferentes, chegando a apresentar uma pequena tabela que contém alguns poucos troncos etnolinguísticos, mas - estranhamente - no tronco Jê não há menção aos Kaingang, que pertencem a esse tronco. Não entendemos o motivo dessa lacuna, talvez por erro do autor - questão delicada em um livro didático que é usado dentro de uma Terra Indígena Kaingang, silenciamento e invisibilização que devem soar estranhos aos estudantes Kaingang. O autor cita, 
inicialmente, a importância do respeito à diversidade indígena, mas não discute essa diversidade e, meia página depois, já muda de assunto sob o subtítulo "As semelhanças entre os indígenas": "Se, por um lado, há diferenças entre os povos indígenas, por outro, há também semelhanças, isto é, um conjunto de características comuns que os diferencia dos não indígenas" (Boulos Jr., 2015, p. 97). Destaca, então, o que chama de "semelhanças": "A terra, para os indígenas, é de quem trabalha; a divisão do trabalho é feita por sexo e idade". Ele cita que em todas as comunidades indígenas algumas tarefas são feitas por homens e outras por mulheres, e coloca o "plantar" como uma atividade "feminina". Isso nos fez perceber que o autor realmente desconhece a realidade das comunidades indígenas, pois em todas as comunidades que visitamos são os homens que cuidam do plantio. ${ }^{6}$

Ou seja, o autor anuncia que irá tratar das multiplicidades dos indígenas e que é importante pensar nisso, mas não executa isso no texto e logo cai no discurso homogeneizador. Ele chega a admitir seu desconhecimento no assunto: "As histórias e as culturas indígenas marcaram profundamente nosso modo de ser, nossos hábitos e nossa língua. Apesar disso, sabemos pouco sobre sua contribuição para a história e cultura brasileira" (Boulos Jr., 2015, 6º ano, p. 96).

Esse capítulo sobre os indígenas está localizado entre um capítulo da pré-história e outro sobre a Mesopotâmia antiga, o que reforça o estereótipo do indígena como "povo do passado". Isso em um livro que está sendo usado como material didático em uma escola indígena, dentro de um território indígena.

O que mais nos preocupou na narrativa dessa coleção foi o distanciamento da presença indígena na História do país: o indígena aparece na coleção nas fases do período colonial, como oprimidos, e depois desaparecem do discurso histórico. Depois, narra-se todo o período imperial, a primeira República, os golpes militares e a redemocratização, e somente nesse ponto há uma pequena citação de quatro páginas no último livro, onde se discutem um pouco as demandas de luta dos povos indígenas em geral. Séculos e séculos são narrados sob silenciamento da presença indígena. Por que esse esquecimento dos indígenas na narrativa? Um jovem indígena estudante, ou um jovem não indígena na Escola poderiam se perguntar: mas, afinal, onde estiveram os indígenas por todos esses séculos, antes de voltarem a aparecer repentinamente no século XXI? E nos perguntamos: quais os critérios políticos de escolha das temáticas 
abordadas em um livro didático? E até que ponto essas escolhas políticas por alguns silenciamentos influenciam na educação para o respeito e valorização das identidades e diversidades?

Em quase todas as Escolas visitadas encontramos diversos tipos de pequenos livros bilíngues (na língua indígena e em português) com histórias dos antigos das comunidades, com desenhos das crianças indígenas e com diagramação simples, singelos e bonitos. Livros criados para uso local, voltados sempre para o Ensino Fundamental, para serem usados no processo de alfabetização bilíngue e de aproximação da história e cultura da comunidade. É o caso, para citar um exemplo, da coleção Mitos e Histórias do povo Guarani (Mello, 2013), criada pelos professores e educandos indígenas das comunidades Guarani Nhandewa das terras Indígenas Pinhalzinho, Laranjinha, Iwy Porã e São Jerônimo (com apoio, na organização, da antropóloga Gláucia Buratto Rodrigues de Mello).

Porém, não encontramos nenhum desses materiais, realizados pelos indígenas com histórias da comunidade, voltado para o Ensino Médio.

\section{RETORNANDO À NOSSA QUESTÃO CENTRAL}

Com base nessas análises e nas falas dos indígenas podemos chegar a algumas conclusões sobre a questão fundamental: "Como pensar uma maneira mais respeitosa e profunda de se ensinar sobre as Histórias e Culturas indígenas em sua pluralidade e multiplicidade?"

Percebemos que algumas ações são fundamentais:

Colaborar para que os indígenas sejam os protagonistas da sua História. Sabe-se que a narrativa hegemônica e oficial da História do país foi escrita somente pelas mãos do não indígena e enraizada em uma lógica colonizadora. Sabendo do perigo de uma história única, torna-se essencial uma história contada pelos próprios indígenas, sendo estes os protagonistas da história brasileira.

Colaborar na luta dos indígenas para adentrarem ativamente campos políticos e de influência de poder e saber onde antes estavam ausentes, como nas Universidades, nos Museus e nas publicações de livros e pesquisas sobre sua Cultura. 
Valorizar o contato e convivência, conhecer e conviver com os indígenas, para que os conhecimentos equivocados e os preconceitos deem lugar a um conhecimento mais real sobre as diferentes etnias e sociedades indígenas do Brasil, para que se presencie pessoalmente a profundidade e riqueza da sabedoria desses povos, para que os próprios indígenas expliquem suas lutas e problemáticas.

\section{REFERÊNCIAS}

BITTENCOURT, Circe. Livros didáticos entre textos e imagens. In. BITTENCOURT, Circe (org.). O saber histórico na sala de aula. 2. ed. São Paulo: Contexto, 1998.

BOULOS JR., Alfredo. História, sociedade \& cidadania. 2. ed. São Paulo: FTD, 2016.

BRASIL. Ministério da Educação. Guia de livros didáticos PNLD 2017: História Ensino fundamental anos finais. Brasília: MEC, 2016.

FREIRE, José Ribamar Bessa. Cinco ideias equivocadas sobre o índio. Revista do Centro de Estudos do Comportamento Humano (CENESCH), Manaus, n. 1, p. 1733, set. 2000.

LIMA, Mirna. Porta aberta - História. São Paulo: FDT, 2011.

MELATTI, Julio Cezar. Índios do Brasil. 7. ed. São Paulo: Hucitec, 1993.

MELLO, Gláucia Buratto R. de (org.). Mitos e Histórias do povo Guarani. Terra indígena Pinhalzinho, Laranjinha, Iwy Porã e São Jerônimo, 2013. 5 v.

MOTA, Lúcio Tadeu. Os Kaingang do vale do rio Ivaí: história e relações interculturais. Maringá: Eduem, 2008.

PIMENTEL, Spensy. O índio que mora na nossa cabeça: sobre as dificuldades para entender os povos indígenas. São Paulo: Prumo, 2012.

ZAMBONI, Ernesta; BERGAMASCHI, Maria Aparecida. Povos indígenas e ensino de história: memória, movimento e educação. In: CONGRESSO DE LEITURA DO BRASIL (COLE), 17., 2009, Campinas. Anais..., Campinas: ALB, 2009. Disponível em: www.alb.com.br. Acesso em: 5 ago. 2017.

\section{Entrevistas}

DOMINGUES, Jefferson Gabriel. Entrevista concedida na Terra Indígena Pinhalzinho, Paraná, 2017.

JORGE, Cristiano Góje. Entrevista concedida na Terra Indígena Apucaraninha, Paraná, 2017.

NARCISO, Ana Paula Goj Téj. Entrevista concedida na Terra Indígena Xapecó, Santa Catarina, 2017. 
VELÁSQUEZ, Pedro Pablo. Entrevista concedida na Terra Indígena Pinhalzinho, Paraná, 2017.

ALVES, Claudinei Ribeiro. Entrevista concedida na Terra Indígena Ywi Porã, 2017.

SILVA, Suely; SILVA, Dival. Entrevista concedida na Terra Indígena São Jerônimo, 2017.

\section{NOTAS}

${ }^{1}$ Doutora em Educação pela Universidade Estadual de Maringá (UEM).

${ }^{2}$ A coleção é utilizada atualmente pelas Escolas Municipais do município de Jacarezinho (PR). A coleção se compõe de 4 volumes destinados aos $2^{\circ}, 3^{\circ}, 4^{\circ}$ e $5^{\circ}$ anos no Ensino Fundamental.

${ }^{3}$ A coleção é utilizada na Escola Indígena Benedito Rokág, em território Kaingang localizado na Terra Indígena Apucaraninha (que fica entre os munícipios de Londrina e Tamarana, PR) e traz livros voltados para o Ensino Fundamental (a partir do $6^{\circ}$ ano) e todo o Ensino Médio.

${ }^{4} \mathrm{Na}$ realidade, a população indígena representa aproximadamente $5 \%$ da população mundial, cerca de 370 milhões de indígenas vivem em torno de 90 países. São mais de 5 mil grupos diferentes que falam 7 mil línguas. No Brasil, segundo o Censo Demográfico IBGE do ano 2010, no Brasil havia 817.963 indígenas que, de acordo com suas diversidades, estão presentes nas cinco regiões do Brasil. São 305 etnias, que falam 274 línguas. Na região Norte concentra-se o maior número de pessoas, sendo aproximadamente $37 \%$ do total dos indígenas no país. $\mathrm{E}$ o contingente populacional indígena continua crescendo significativamente.

${ }^{5}$ Trata-se de uma fala de Davi Kopenawa Yanomami, apresentado como um "pajé". A fala foi realizada em Londres, no ano de 2007, no Parlamento Britânico. Pela sua raridade em um Livro Didático, fazemos questão de reproduzi-la aqui: "Na nossa terra temos muitas serras. Dentro das serras moram os xaporis, hekuras, os espíritos da natureza. As serras são lugares sagrados [...] onde os espíritos dos mortos retornam para viver. Os nossos velhos deixaram seus espíritos nesses lugares. Nós, Yanomamis, queremos que as serras sejam respeitadas, não queremos que sejam destruídas. Queremos que esses lugares sejam preservados para não acabar com a nossa história e com nossos espíritos" (BOULOS JR., 2015, p. 322). Essa fala está colocada na parte final do último livro da coleção, do $9^{\circ}$ ano, na temática Brasil Contemporâneo dentro da "Nova Ordem Mundial".

${ }^{6} \mathrm{E}$ com isso não estamos afirmando que em todas as comunidades indígenas os homens é quem são responsáveis pelo plantio, estamos apenas querendo dizer que a tentativa de homogeneizar a multiplicidade da cultura indígena é complicada, algo delicado e que deve ser feito com mais cautela para que não se transmitam estereótipos sem fundamento.

Artigo recebido em 6 de fevereiro de 2019. Aprovado em 19 de março de 2019. 